\title{
El desarrollo de actividades empresariales por la Administración: La instrumentalización de las formas del derecho privado. Breves notas sobre la "huida del derecho administrativo" y las sociedades públicas en el sistema colombiano y español
}

\footnotetext{
Pedro T. Nevado-Batalla Moreno.

Doctor en Derecho, Universidad de Salamanca, España; Licenciado en Derecho por la Universidad de Salamanca; Profesor Titular de Derecho Administrativo, Universidad de Salamanca.

E-mail: pnevado@usal.es

Carolina Bravo Vesga

Doctorando en Derecho (C), Universidad de Salamanca; Abogada Universidad Santo Tomás -Seccional Bucaramanga. Investigadora del Área de Derecho Administrativo, Universidad de Salamanca, España. E-mail: ascabra@hotmail.com
}

\begin{abstract}
Resumen
El debate sobre la utilización de instituciones privadas por parte de los poderes públicos para la participación e intervención en la actividad económica, nos sitúa dentro de la denominada huída al derecho privado por parte de las Administraciones Públicas. Este fenómeno ha ido decantando problemas en torno a la naturaleza jurídica real de las figuras jurídicas importadas del derecho privado utilizadas por la Administración y a su correspondiente normativa reguladora pública, privada o mixta. En el presente artículo, se pretende analizar las posibilidades constitucionales y legales de las que dispone la Administración Pública, dentro de un estado social de derecho, para realizar sus fines a través del uso de instrumentos propios del derecho privado. Afirmado lo anterior, se definirán en primer lugar, las pautas que debe tener en cuenta la Administración Pública para elegir entre instrumentos de carácter público o privado. En segundo lugar, se hará lo propio con los criterios conforme a los cuales se debe determinar la naturaleza jurídicopública o jurídico-privada de un ente utilizado por la Administración. Finalmente, se abordará la problemática inherente a la naturaleza jurídica de la Sociedad Anónima Pública y al carácter público o privado de su regulación.
\end{abstract}

\section{Palabras Clave}

Administración Pública, Administración instrumental, Constitución económica, huída del derecho administrativo, servicios públicos, empresa pública, control público.

\begin{abstract}
Abstrac
The debate about the use of private institutions by the public administration to participate and intervene in the economy, place us within the so called "flight" of the Public Administration to the private law. The main problems generated by these phenomenon's deal with the legal nature of these instruments regulated by private law but used by the Administration and, therefore, the confusion of its regulation (public law, private law or mixed). In this paper, it will be defined, first of all, the steps (and the criteria) that the Administration has taken into account in order to choose between private or public law regulated instruments. After that, it will be necessary to discuss the criteria according to which the effectiveness of public-law o private-law nature of an entity used by the Administration will be determined. Finally, it will be briefly analyzed the problem related to the juridical nature of a public corporation regarding its public or private regulation.
\end{abstract}

\section{Key words}

Public Administration; Instrumental Administration; Economic Constitution; flight from Administrative law; public service; public corporation; public control. 

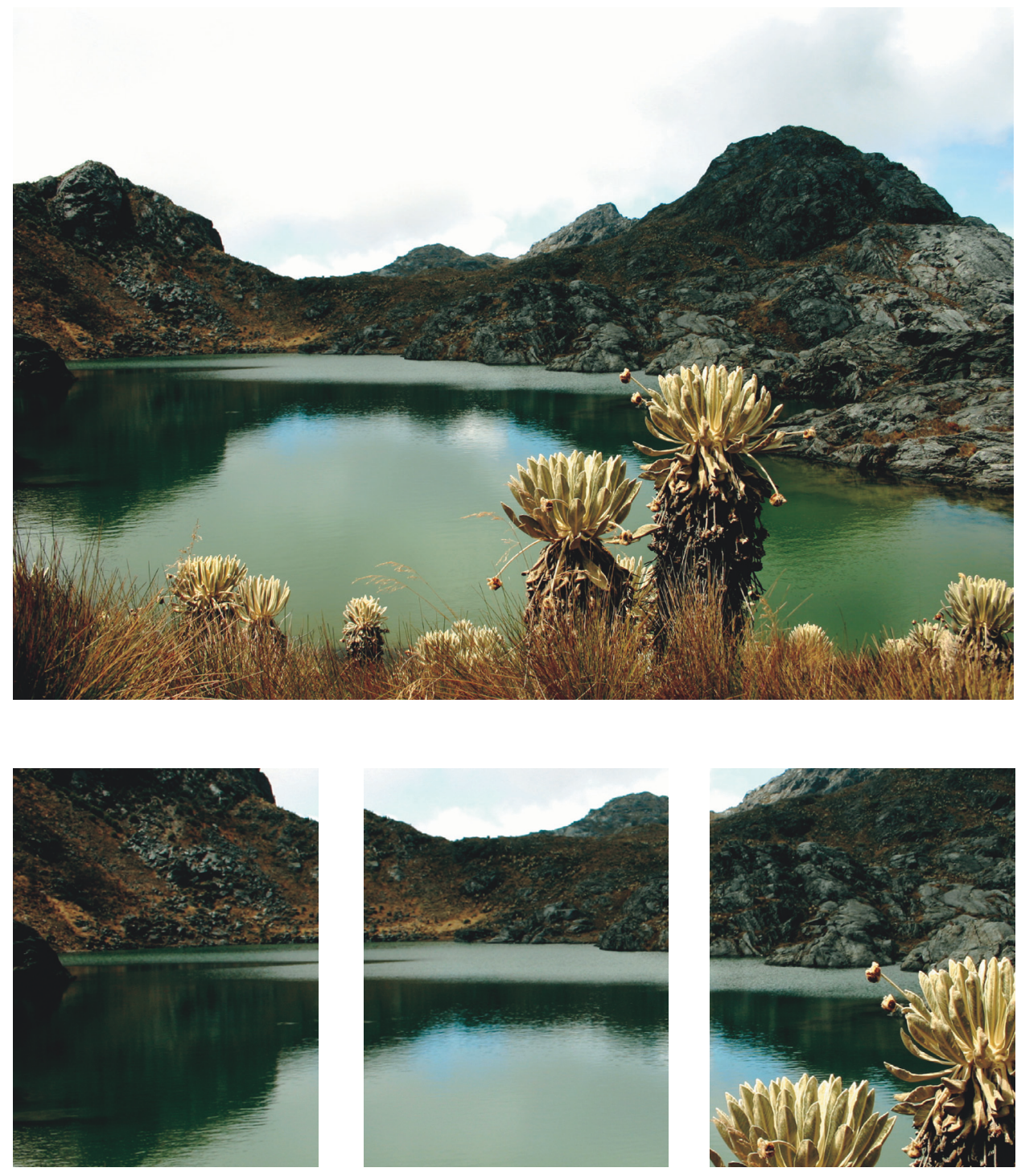

"Laguna: Verde de Morro Nevado" 


\section{EI desarrollo de actividades empresariales por la Administración: La instrumentalización de las formas del derecho privado. Breves notas sobre la "huida del derecho administrativo" y las sociedades públicas en el sistema colombiano y español*}

Pedro T. Nevado-Batalla Moreno, Carolina Bravo Vesga

\section{Introducción}

Históricamente, la presencia del "Sector Público" en el marco de las relaciones económicas ha respondido a constantes cambios ideológicos. Los estudios de la intervención de lo público en la economía se han realizado tanto desde el punto de vista de la intervención directa del Estado (modelo intervencionista), como desde la óptica de los derechos constitucionales de la libertad de empresa y la libre

Este trabajo se enmarca en el Proyecto de Investigación "El blanqueo de capitales en el marco de la moderna delincuencia económica y la financiación del terrorismo", financiado por el Ministerio de Ciencia e Innovación del Gobierno de España (DER2009-13351) y en el Proyecto de Investigación "Corrupción, fraude y delincuencia económica: vías de integración jurídica desde las experiencias europea e iberoamericana", financiado por la Consejería de Educación de la Junta de Castilla y León (SA033A10-1). 
competencia (modelo liberal) 1 . Sea en un modelo como en otro, la Administración pública se ha caracterizado por la utilización de instituciones jurídicas propias del derecho privado, evadiendo, en muchos casos, los rigores inherentes al principio de legalidad al que está sujeta. En este contexto, se alzan las posiciones administrativistas que reclaman la vuelta al derecho público, a la aplicación de los principios del derecho administrativo para aquellas actividades que, con independencia de la formas jurídico-privadas utilizadas por Estado, conlleven el ejercicio de potestades propias de la Administración o impliquen el ejercicio de "actividades de carácter prestacional que [tengan] una especial significación para la comunidad"2. Esta postura deja en manos del legislador y del poder discrecional de la Administración la instrumentalización de formas iusprivatistas (particularmente societarias) para la intervención directa del Estado en actividades industriales, comerciales y/o prestacionales que no resulten esenciales para los administrados. En este marco, el posicionamiento mercantilista frente a la "empresa pública" se preocupa especialmente por definir el régimen aplicable a las entidades de naturaleza privada, utilizadas por los poderes públicos con la finalidad última de que el Estado pueda comportarse como un verdadero agente en el mercado. Por otra parte, el resultado del boom privatizador reabrió el debate sobre la utilización por los poderes públicos de formas societarias para participar en la economía ${ }^{3}$, sobre su naturaleza, regulación y sobre el fenómeno denominado "huida del derecho administrativo"4. En este trabajo, haremos referencia a las posibilidades con que cuenta el Estado para escoger entre instituciones de derecho público o derecho privado para el cumplimiento de sus fines constitucionales. Asimismo, hablaremos del debate acerca de los criterios para elegir entre unos u otros instrumentos. La discusión finalizará abordando problemáticas inherentes al uso de los tipos societarios por el Estado para intervenir en la economía y preguntándonos si, dada la legislación administrativa vigente para su constitución, organización (adquisición y enajenación de acciones, orientación general de sus fines, modificación de estatutos etc.) y extinción, se debe seguir afirmando la naturaleza privada de dichos entes.

1 A estos criterios se une, en los países integrantes del Mercado común Europeo, el problema de adecuación de la regulación a las normas comunitarias.

2 Rivero Ortega, R., Administraciones Públicas y Derecho Privado, Madrid, 1998, Pág. 125.

3 Sobre este punto: Alonso UrebA, A., La empresa pública: aspectos jurídicosconstitucionales y derecho económico, Madrid, 1985,

4 Término integrado a los estudios de derecho administrativo en los años '60 por el Prof. Clavero Arevalo, M., "Personalidad jurídica, derecho general y derecho singular en las Administraciones Autónomas", en Documentación Administrativa, Núm.58, 1962, pág. 13 y ss. 


\section{Marco Constitucional Económico General de Intervención Pública en la Economía}

A lo largo de las diferentes etapas, acerca del papel del estado en la economía se han enfrentado posiciones intervencionistas y liberales. Durante el Siglo XIX, el sistema liberal - caracterizado por la defensa de las libertades, la autorregulación del mercado y la reducción del papel del Estado en la economía - marcó la línea a seguir. A finales del mismo siglo, el Estado, con la finalidad de procurar el bienestar a sus administrados, asume la dirección de la regulación de la economía. En este marco, surgen las denominadas "constituciones económicas", caracterizadas por delimitar la presencia del Estado en la actividad económica ${ }^{6}$.

En el marco de los Estados sociales y democráticos de derecho Colombiano y Español, el articulado que compone la "constitución económica" habilita al propio Estado para intervenir de manera directa e indirecta en la economía dentro de un "modelo social de mercado"7 (Sentencia C-83/1999). El reconocimiento de los

5 Menéndez Menéndez, A., Consitución, sistema económico y derecho mercantil Madrid, 1985, pág. 29. "En sentido estricto hablamos de constitución económica para referirnos al conjunto de normas que (...), con rango constitucional, establecen la legitimación para ejercer la actividad económica, el contenido de las libertades y los poderes que se deriven de esta legitimación, las limitaciones que afectan a los mismos y la responsabilidad que grava su ejercicio, así como, los instrumentos y medidas con los cuales el Estado puede actuar o intervenir en el proceso económico". En el mismo sentido vid: DuQue, J., Constitución económica y Derecho Mercantil en La reforma de la legislación mercantil, Madrid, 1978, pág. 4 y ss; Font Galan, J., "Notas sobre el Modelo Económico de la Constitución Española”, en Revista de Derecho Mercantil Núm. 152, 1979, pág.5 y ss.

6 Presencia que se delimita desde la exposición de de los fines esenciales del estado en el Preámbulo, Art. 2 CN y Art. 1 CE.

7 A este respecto, Menéndez Menéndez, A., Consitución,...Ob., cit., pág. 32 y ss. nos comenta dos posiciones básicas sobre el modelo económico elegido por la CE de 1978: la primera de ellas "llega a la conclusión de que lo que se ha constitucionalizado es un modelo económico de economía de mercado, concreto, fijándose con ello claros y terminantes límites a la intervención estatal (...) La otra orientación entiende, por el contrario, que la consitución ha dado entrada a un sistema de economía de mercado abierto, es decir, a un modelo flexible, que habilita para distintas opciones políticas, tanto una más conservadora (de corte liberal-capitalista), como otra más avanzada (de corte socialista), debiendo respetarse en todo caso ... el contenido de los derechos fundamentales del Estado social y democrático de derecho". Sobre este punto: Esteban Velasco, El poder de decisión en las sociedades anónimas, Madrid, 1982, pág. 614 y ss yDuque, J., Constitución económica y Derecho Mercantil en La reforma de la legislación mercantil, Madrid, 1978, pág. 71 y ss. En Colombia, como lo ha manfiestado la Corte Constitucional en la sentencia arriba mencionada,"si bien no existe un modelo económico específico, exclusivo y excluyente, al que actualmente impera, fundado en un Estado Social de Derecho, muestra una marcada ingerencia del poder público en las diferentes fases del proceso economico, procurando establecer límites razonables a la actividad privada (...) y garantizar el interés colectivo (...) El orden público económico se consolida sobre la base del equilibrio entre la economía libre, en la que participan activamente los sectores público, privado y externo y la intervensión estatal que busca manterner el orden y garantizar la equidad en las relaciones económicas, evitando los abusos y arbitrariedades que se pueden presentar en perjuicio de la comunidad". 
derechos a la libertad de empresa ${ }^{8}$ y a la iniciativa pública en la economía legitima la intervención estatal directa (es decir, faculta al Estado productor y distribuidor de bienes y servicios para actuar como un agente económico más en mercado). Por su parte, aquellas normas constitucionales que otorgan al Estado la potestad reguladora del sistema económico ${ }^{10}$ permiten el uso de múltiples instrumentos normativos para intervenir de manera indirecta en la actividad económica. La compatibilidad entre las dos formas de intervención estatal descritas (fundamentadas constitucionalmente en la libertad de empresa y la potestad de regulación económica) ha sido objeto de constantes discusiones: la posición mayoritaria encuentra un punto de equilibrio, entendiendo la potestad de regulación económica como "la planificación del orden económico dirigida a la mera regulación normativa de la estructuras (competencia, circulación monetaria etc.) de una economía de mercado""li (legislación que, en todo caso, ha de encontrar su marco en la propia Constitución, partiendo de la concepción del Estado como social y democrático de Derecho). Asimismo, se ha entendido la libertad de empresa como "un derecho subordinado a los intereses generales, sin merma de su contenido esencial (...), en el sentido de que (...) se está potenciando también la función social de la actividad del empresario"12.

A efectos de este trabajo, de manera particular, nos interesa detenernos en el análisis de la normativa habilitante para la intervención directa del Estado en la economía. En este contexto, son múltiples las herramientas jurídicas de las que dispone el Estado para realizar los objetivos fijados por la Constitución ${ }^{13}$. En particular, ni la Carta Magna colombiana (CN) ni la española (CE) consagran un modelo económico preciso. Por el contrario, al considerarse estas últimas constituciones abiertas ${ }^{14}$, admiten la libertad de formas, es decir, la utilización de diversas herramientas, tanto de de derecho público como de derecho privado, para la gestión u organización de las

8 Art. $333 \mathrm{CN}, 38 \mathrm{CE}$.

9 Art. $338 \mathrm{CN}, 128.2 \mathrm{CE}$.

10 Titulo VII CE, XII CN. En estos artículos se encuentran los fundamentos constitucionales del hoy llamado por la Doctrina Derecho Administrativo-económico. En este sentido: García RuIz, E., La nueva sociedad anónima pública, Madrid, 2006, pág. 26.

11 García Echevarría, S., "El orden económico en la Constitución”, en Libre empresa, Madrid, 1982, pág. 50.

12 Verguez, M., "El derecho mercantil ante la Constitución española”, en Lectura sobre la Constitución española, Madrid, 1979, pág. 495.

13 Sobre el carácter "abierto" de la CN teniendo en cuenta su no prefiguración de instrumentos para alcanzar las objetivos deseables lo que no excluye ciertos límites a la política económica el trabajo de: Uprimny, R. and Rodríguez, C., "Constitución y modelo económico en Colombia: hacia una discusión productiva entre economía y derecho", en Debates de Coyuntura Económica, Núm. 62, 2005, pág. 23-40. Respecto al el carácter "abierto" de la CE vid: Esteban Velasco, El poder ... ob.cit., pág. 618 y ss. y Font Galan, "Notas sobre el Modelo “, en Revista ... ob. cit., pág. 211 y ss.

Ibidem. 
actividades económicas (eso sí, dentro de ciertos límites impuestos por las mismas normas fundamentales a quienes tienen asignada la competencia de formulación de la política económica ${ }^{15}$.

En el marco constitucional descrito, se resaltan límites como: la obligación de los poderes públicos (entre ellos, la Administración) de servir al interés general (Art. 103.1 CE, 2CN) la división competencial ${ }^{16}$, las reglas del procedimiento a seguir para producción normativa ${ }^{17}$ (Art.105CE, 334CN), el contenido mínimo de la extensa carta de derechos y libertades que vincula directamente a todos los poderes públicos pudiéndose invocar ante los Tribunales $^{18}$ (Art. $53 \mathrm{CE}, 86 \mathrm{CN}$ ), los principios que enmarcan la actuación de las autoridades económicas (p.e. financiación de vivienda $^{19}$ [Art.51CN], sistema tributario ${ }^{20}$ [Art. $\left.363 \mathrm{CN}\right]$, sometimiento a la normas presupuestarias [Art. 134.2 CE], sometimiento a órganos de control [Art. 136 CE], en general, toda la regulación sobre Hacienda y Economía [Titulo VII CE, XII $\mathrm{CN}]$ ), la finalidad social del Estado y los servicios públicos (Art. $42 \mathrm{CE}, 365 \mathrm{CN}$ ), la demanialización del subsuelo y otras riquezas (Art.132 CE, Art.332 CN), el deber de las autoridades públicas de desarrollar políticas orientadas a la satisfacción de los derechos sociales (Art. $39 \mathrm{CE}, 2 \mathrm{CN}^{21}$ ), los límites de procedimiento respecto de las transferencias y la financiación a entidades del sector público (Art. $346 \mathrm{CN}$ ), la estabilidad económica y el pleno empleo (Art. $40 \mathrm{CE}, 334 \mathrm{CN}$ ), la defensa de los consumidores y usuarios (Art. 51.1CE, $369 \mathrm{CN}$ ), el reconocimiento a la iniciativa pública en la actividad económica (Art. $128 \mathrm{CE}, 334 \mathrm{CN}$ ), la posibilidad de reservar al sector público en régimen de monopolio determinados servicios esenciales (Art. $128 \mathrm{CE}, 336 \mathrm{CN}$ ), la admisión de la intervención privada cuando el interés general lo exija (Art. 128.2 CE), la libertad de la iniciativa privada (Art.333 CN), el reconocimiento de la propiedad intelectual (Art. 20.1, 33.1, 149.9 CE, 61 CN), la

15 Sobre los límites impuestos por la misma carta magna a la política económica y la diferencia entre constituciones abiertas y "plenamente neutras” vid: Menéndez MenÉndez, A., Consitución,...ob. cit., pág. 33; Uprimny, R. and Rodríguez, C., "Constitución y modelo ...”, en Debates ... ob. cit.., pág. 29 y la Sentencia de la Corte Constitucional Colombiana C-040/1993.

16 Sentencia de la Corte Constitucional C-481/99 sobre la obligación legal del Banco de la República de proyectar la inflación por debajo del porcentaje de la misma correspondiente al año anterior. En ella, la Corte consideró que una disposición con tal contenido era violatoria de la discrecionalidad del Banco en el manejo de la política monetaria. De la misma corporación la Sentencia C-160/00 sobre las competencias de las entidades territoriales. En la misma línea Sentencia del Tribunal Constitucional Español (STC) 52/1994.

17 Sentencia C-557/00 referente a planes de desarrollo, C-737/01 referente a la ley de regalías y C-122/98 respecto a los decretos de emergencia económica.

18 Respecto a la protección de derechos fundamentales Sentencias: C-586/01 derechos adquiridos, C-754/04 régimen de transición pensional, C-671/2002 sistema de salud de las fuerzas militares y de policía.

19 Sentencia C-747/99 de inconstitucionalidad del sistema UPAC.

20 Sentencia C-136/99 sobre el sector financiero y cooperativo.

21 Sentencia C-149 de 1993. 
responsabilidad del personal al servicio de la administración (Art. 91, 201, $210 \mathrm{CN}$; 9.3 CE), el control por las autoridades judiciales del cumplimiento de las obligaciones del Legislador y la Administración frente a los derechos sociales dentro del marco de la propia constitución (Art. 106.1CE, Art. 6 CN).

De lo anterior, se infiere que, dentro de un modelo de Estado Social de Derecho, no hay espacio "para ignorar los elementos públicos y sociales (...) pretendiendo afirmar la validez de un puro sistema de economía liberal con relaciones de producción simplemente autorreguladas por las fuerzas del mercado, ni tampoco, para un sistema de de economía colectivizada o de dirección central que ignora abiertamente la libertad de empresa en el marco de la economía de mercado"22. El Estado como director de la economía (Art. $334 \mathrm{CN}$ ), dotado constitucionalmente de iniciativa en la actividad económica (Art. $128 \mathrm{CE}$ ), debe actuar, por regla general, en posición de igualdad con las empresas privadas y sólo excepcionalmente -cuando el interés general lo aconseje-, lo hará mediante el uso de técnicas monopolísticas o de intervención empresarial. Independientemente de si escoge herramientas de derecho público o de derecho privado para el cumplimiento de sus fines, el "Sector Público" 23 , cuando decida intervenir en actividades económicas, deberá hacerlo en condiciones de igualdad y bajo el respeto de la normativa de libre competencia ${ }^{24}$.

Este principio -conocido como el "principio de paridad de trato" 25 - impone la aplicación a las empresas públicas de las mismas normas aplicables a las empresas privadas, con el propósito de que ambas compitan en igualdad de oportunidades. Lo anterior implica la supresión de los privilegios que, de hecho o de derecho, puedan disfrutar las empresas consideradas como públicas, con la pretensión de que los "los poderes públicos", al momento de respaldar económicamente a sus empresas, se comporten de la misma manera que un empresario particular, es decir, respetando los criterios de racionabilidad y rentabilidad económica.

22 Menéndez Menéndez, A., Consitución,...ob. cit., pág. 33. Asimismo: Duque, J., Constitución económica ... ob. cit., pág. 72 y GARrido FALla, F., "Introducción general”, en El modelo económico de la Constitución Española, Madrid, 1981, pág. 49 y ss.

23 Término utilizado para definir la actividad económica estatal dirigida a la producción de bienes y prestación de servicios independientemente de la forma jurídica que utilice. Sobre este punto: Martín Retortillo, S., Derecho Administrativo Económico, Madrid, 1988, pág. 36 y ss. y García Ruiz, E., La nueva sociedad ... ob. cit., pág.27. Este vocablo es utilizado en los Art. 341 CN y 134.2, 136 y $128.2 \mathrm{CE}$.

24 Cfr. Menéndez Menéndez, A., Consitución,...ob. cit., pág. 36 y ss. Así mismo, sobre la obligación constitucional del Estado de actuar en el campo económico conforme al régimen de competencia: Art. 128 CE y 334 CN, Art. 3 Ley 3 de 1991, de 10 de enero, de competencia desleal, los Art. 1-5 de la Ley 15 de 2007, de 3 de julio, de defensa de la competencia, Art. 1-3 de la ley 256 de 1996, de 15 de enero, por la cual se dictan normas sobre competencia desleal. Sobre este punto el trabajo de: Morisi, M., "Aspectos esenciales de la relación entre el Estado y la Economía en la Constitución de la crisis", en La Constitución Española de 1978, Madrid, 1980, pág. 374 y ss.

25 Art. 106 del TFUE (Tratado de Funcionamiento de la Unión Europea). Sobre el principio de paridad de trato: Salvador Armendáriz, M., Banca Pública y Mercado, Madrid, 2000, pág. 279 y ss. 
La doctrina mercantilista ${ }^{26}$ moderna exige que, cuando el Estado decida actuar revestido de formas organizativas de derecho privado, amolde su estructura y funcionamiento a la estructura y funcionamiento de las empresas privadas, equiparando al máximo su régimen jurídico al privado. Ello con el propósito de evitar cualquier brote de disparidad de trato entre el "Sector público" y el privado $\mathrm{y}$ de promover una actuación eficaz del las empresas privadas de capital público o mixto (entendiendo por éstas, aquéllas que ejercen actividades de dación o puesta en el mercado de bienes, o aquéllas que no prestan servicios públicos considerados esenciales).

Ni la Constitución colombiana ni la española excluyen sectores de la intervención del Estado. La responsabilidad de determinar en cuáles de ellos deberá actuar el Estado le es asignada al Legislador (mediante el procedimiento legislativo caracterizado por su publicidad) quien, a su vez, podrá, con mayor (Art.105c CE) o menor margen (Art. 150 - 189.11,21,22,24,26 CN), habilitar al poder ejecutivo para definir, conforme a la política económica dictada, la mayor o menor amplitud del sector público ${ }^{27}$. "La relativización de la reserva de Ley ha favorecido la renuncia del legislador a dictar la necesaria regulación de los elementos esenciales del recurso a las fórmulas organizativas sujetas al derecho privado (...). La reserva de Ley en materia organizativa puede ser satisfecha mediante disposiciones legales que se limiten a regular las condiciones previas de la utilización de los tipos organizativos sujetos a derecho privado, ofreciendo pautas que racionalicen su elección" 28 y garanticen el respeto por los derechos fundamentales.

Hasta aquí, hemos dicho que el Estado está facultado para actuar como agente económico en cualquier sector de la economía (sectores definidos, bien por Legislador, bien por la Administración) y también a utilizar, para ello, la forma que mejor le permita cumplir con sus fines ya sea jurídica-pública ya sea jurídicoprivada. Esta última afirmación ha hecho que la doctrina administrativista ${ }^{29}$ se plantee los siguientes cuestionamientos: ¿por qué la Administración Pública actúa mediante sociedades mercantiles o simplemente recurre al Derecho privado? y, una vez definidas las actividades económicas en las que el Estado va a intervenir de manera directa, ¿cuáles son las pautas a seguir por la Administración para determinar

26 Entre ellos: Alonso UrebA, A., "El marco constitucional económico español y la adehesión a las Comunidades Europeas", en Tratado de Derecho Comunitario Europeo, vol. I, Madrid, 1986, pág. 263 y ss; Vincent Chulia, F., "Poderes públicos y derecho de la competencia", en Revista General de Derecho, Núm.583, 1993, pág. 340 y ss., García Ruiz, E., La nueva sociedad ... ob. cit., pág.115 y ss.Rodríguez Curiel, "El control comunitario de las ayudas públicas", en Noticias de la Unión Europea, Núm 75, 1991, pág. 89 y ss.

27 García Ruiz, E., La nueva sociedad ... ob. cit., pág.27.

28 En este sentido Rivero, pág. 19.

29 Entre ellos: Parada Vázquez, R., Derecho Administrativo II. Organización y empleo público, Madrid, 2008, pág. 234; Martín Retortillo, S., "Reflexiones sobre la huida del derecho administrativo", en Revista de Administración Pública, Núm. 140, 1996, pág. 25 y ss. 
si actúa mediante instituciones reguladas por el derecho público o, por el contrario, utiliza los instrumentos tradicionalmente pertenecientes al derecho privado?

\section{Sobre el primer cuestionamiento. Algunas anotaciones sobre la "huida" del derecho administrativo por parte de la Administración}

La multiplicidad de fines constitucionalmente asignados al Estado social y democrático de derecho ha conllevado el protagonismo económico de Estado y la asunción, por parte del mismo, de actividades económicas de carácter industrial y mercantil: como se ha observado, "el individuo se convierte en el acreedor de una serie de prestaciones que garantizan su existencia (...) y que caracterizan una administración prestadora de servicios" ${ }^{\prime 3}$. Siempre con la finalidad de cumplir con los fines constitucionales a ella asignados, la Administración, en el ejercicio de sus potestades, "gestiona la organización de medios personales y materiales cuya actuación concreta resulta necesaria para alcanzar la satisfacción de los intereses públicos y las necesidades colectivas de los ciudadanos" ${ }^{31}$. Y fue precisamente la "creencia generalizada" de que los fines mencionados no habían sido completamente satisfechos con la utilización de herramientas o formas de organización iuspublicistas lo que ha justificado el uso de instituciones iusprivatistas por parte de la Administración, bajo el pretexto de poder operar en el mercado de forma más ágil y con criterios económicos, sustrayéndose a los incómodos controles propios del derecho administrativo ${ }^{32}$.

La Administración, en su anhelo de adoptar formas cada vez más ágiles y "eficientes", terminó otorgando autonomía a sus tradicionales "entes instrumentales" 33

30 Garrido Falla, F., "El concepto de servicio público en el Derecho Español”, en Revista de Administración Pública, Núm. 135, 1994, pág.22.

31 Idem, pág. 9; En la misma línea: García de Enterría, E. and Fernández Rodríguez, T. R., Curso de Derecho Administrativo vol. I, Madrid, 2008, pág. 402 "La proliferación de entidades institucionales ha venido a compensar el aumento constante de las funciones administrativas en el Estado contemporáneo, evitando que este aumento haya ocasionado una congestión paralizante de los órganos comunes de la Administración”.

32 Cfr. Hourn, R., "La gestion des entreprises publiques et les methodes du droit commercial", en Archives de philosophie du droit, 1952, pág. 82 y ss.

33 Sobre este punto y, propiamente, sobre el fenómeno de la "huída del derecho administrativo" además de la obra citada del Prof. Clavero Arévalo: Ariño Ortíz, G., ¿Privatizar el Estado? un retroceso en el camino de la historia o la antítesis del Estado de Derecho, Madrid, 1994, , Borrajo InIEsta, I., "El intento de huir del derecho administrativo", en Revista Española de Derecho Administrativo, Núm.78, 1993, pág. 233-249, Del Saz Cordero, S., "La huída del derecho administrativo: ultimas manifestaciones, aplausos y críticas”, en Revista de Administración Pública, Núm. 133, 1994, pág. 57-98, Laguna de Paz, J. C., "La renuncia de la Administración Pública al derecho administrativo", en Revista de Administración Pública, 1995, pág. 201-229, MontoyA Marti, E., Las empresas públicas sometidas al derecho privado, Madrid, 1996, , Morillo-Velarde PÉrez, J. I., "La huída del derecho administrativo, la personalidad jurídica de las Administraciones 
mediante la, cada vez más frecuente, conversión de entidades con personería jurídica en organismos independientes y sometidos a la normativa privada ${ }^{34}$. Como se ha acertadamente observado, "los casos de transformación de unas entidades instrumentales en otras con diferente ropaje jurídico se ha convertido (...) en una autentica manía gubernamental" 35 .

Con la misma finalidad (cumplimiento de los fines constitucionales), identificado el sector industrial o comercial en el que considera necesario intervenir o el servicio público que quiere prestar, la Administración, previa habilitación legislativa, crea "empresas públicas" remitidas en su regulación a las normas de derecho privado, con la finalidad última de facilitar su tránsito hacia la privatización. Este modus procedendi no es ni mucho menos baladí: por un lado, los ciudadanos, de "administrados" transitan al status jurídico de "usuarios"; por otro, "la renuncia a la prerrogativa para alcanzar la libertad es una tentación demasiado fuerte, pues la Administración no necesita del ejercicio de las clásicas potestades para situarse en una posición de supremacía con respecto a los particulares" ${ }^{\text {"36. }}$

Incrédula de poder satisfacer de manera eficaz (con observancia de los principios de economía y celeridad), las nuevas necesidades de los ciudadanos dentro de un Estado social de derecho mediante formas regidas por la abultada normativa administrativa, la Administración ha manifestado su preferencia por formas fundacionales, corporativas o societarias propias del derecho privado, persiguiendo el mito de la eficiencia comúnmente asociado al sector privado. Por otra parte, tal elección se ha hecho olvidando que, con independencia de la forma jurídica elegida, la propia Administración tiene el deber -constitucional- de ser una institución eficaz y actuar conforme a los a parámetros, tan propios del sector privado, como la celeridad y economía. En este sentido, resulta particularmente significativo lo dispuesto por el Art. $209 \mathrm{CN}$ "La función administrativa está al servicio de los intereses generales y se desarrolla con fundamento en los principios de igualdad, moralidad, eficacia, economía, celeridad, imparcialidad y publicidad, mediante la descentralización, la delegación y la desconcentración de funciones" y por el Art. 103 CE "1. La Administración Pública sirve con objetividad los intereses generales y actúa de acuerdo con los principios de eficacia, jerarquía, descentralización, desconcentración y coordinación, con sometimiento pleno a la Ley y al Derecho". Estas normas, además constituir los pilares de la regulación de las Administraciones

Públicas y el principio de eficacia. Reflexiones", en Administración Instrumental. Libro Homenaje a Manuel Francisco Clavero Arévalo, vol. II, Madrid, 1994, pág. , SAla Arquer, J., "Huída al derecho privado y huída del derecho", en Revista Española de Derecho Administrativo, Núm. 75 , 1992, pág. 399 -413.

34 Como una referencia transalpino sobre la Administración Instrumental vid: OTTAVIANO, V., Considerazioni sugli Enti Pubblici Strumentali, Padova, 1959,

35 Garrido Falla, F., "El concepto ...", en Revista ..., ob.cit.., pág.18

36 Rivero Ortega, R., Administraciones ... ob. cit., pág. 15. 
públicas colombiana y española (Art. 3 Ley 449/199837; Art. 3.2 Ley 30/1992 ${ }^{38}$ ), detentan primacía respecto al resto del ordenamiento jurídico: ni el Legislador al desarrollarlas ni la Administración al ejercer la potestad organizativa de la función pública pueden permitirse obviarlas ${ }^{39}$.

De todo lo dicho, se colige que: las nuevas formas de organización administrativa (y, entre estas, particularmente el llamado "sector público"), deben ser consideradas desde el marco constitucional descrito, es decir, desde la así llamada "reserva constitucional de derecho administrativo" 40 , esto es, en un escenario que comprende múltiples y diversas técnicas de control previo y posterior en aras de reducir la discrecionalidad de la Administración Pública y salvaguardar, en todo momento, la posición jurídica de los ciudadanos ${ }^{41}$.

La denuncia de los administrativistas frente a la problemática analizada en este apartado, es unánime ${ }^{42}$. No consideran constitucionalmente admisible la "huida" de las instituciones públicas de las reglas propias del derecho administrativo (principios, presupuesto, régimen de personal al servicio, contratación, responsabilidad, contabilidad) y de sus controles, ni su transformación en sociedades reguladas por el derecho mercantil toda vez que no están suficientemente claros y expuestos los criterios de oportunidad por los que se sustituye el régimen de derecho público -que quedan absorbidos en la vaga referencia al mito de la eficacia-.

En este sentido, uno de los ejemplos que más críticas ha recibido por parte de la doctrina administrativista, fue la inicial descentralización y posterior privatización de la Agencia Estatal de Administración Tributaria Española. Esta organización

37 Por la cual se dictan normas sobre la organización y funcionamiento de las entidades del orden nacional, se expiden las disposiciones, principios y reglas generales para el ejercicio de las atribuciones previstas en los numerales 15 y 16 del artículo 189 de la Constitución Política Colombiana y se dictan otras disposiciones.

38 De régimen jurídico de las Administraciones públicas y procedimiento común Español.

39 Sobre la primacía de las normas constitucionales: GARCíA DE ENTERRÍA, E., La Constitución como norma y el Tribunal Constitucional, Madrid, 1985, , SANCHEZ MoRÓN, M., "Notas sobre la función administrativa en la Consitución Española de 1978”, en La constitución española de 1978, Madrid, 1984, pág. 663 y ss.

40 Del Saz Cordero, S., "Desarrollo y criris del derecho administrativo, su reserva constitucional", en Nuevas perspectivas del derecho administrativo. 3 estudios, Madrid, 1993, pág. 178. En contra: Borrajo Iniesta, I., "El intento de...", en Revista ... ob.cit., pág 234.

41 Cfr. Fernández Rodríguez, T. R., Arbitrariedad y Discrecionalidad, Madrid, 1994, pág127 y ss. Sobre la interdicción de los poderes públicos y la protección de las libertades, derechos y garantías remito al estudio de los trabajos de los profesores: García de Enterría, E. and Martínez- CARANDE, La lucha contra las inmunidades del poder en el Derecho Administrativo, Madrid, 1962, y ANDRÉs IBAÑEz, P., "Contra las inmunidades del poder: una lucha que debe continuar", en Revista Española de Derecho Administrativo, Núm.93, 1997, pág. 5-12.

42 Entre ellos: García de Enterría, E. and Fernández Rodríguez, T. R., Curso de ... ob.cit.., pág.367 y ss; Parada Vázquez, R., Derecho Administrativo II. Organización...ob.cit.., pág.230 y ss; Martín Retortillo, S., "Reflexiones sobre la...", en Revista... ob.cit.., pág.25 y ss; Ariño Ortíz, G., ¿Privatizar el Estado?... ob.cit.. 
"agencial" quedó sometida a un sistema híbrido de regulación: por un lado, se remitieron al derecho administrativo aquellas funciones que, para su ejercicio, necesitaban el uso de potestades propias de los poderes públicos (inspección, recaudación) por lo que, los actos emanados en tales condiciones, permanecieron susceptibles de impugnación ante la jurisdicción contencioso-administrativa; por el otro, quedaron sujetas al derecho privado las funciones atinentes a sus relaciones contractuales y laborales. La doctrina prácticamente unánime observó críticamente que, puesto que las potestades de gestión, inspección y recaudación de tributos habían sido, desde siempre, consustanciales a la Administración, la "privatización" de la Agencia Estatal de Administración Tributaria era dudosamente legítima, ya que éstas mismas y no otras eran sus principales funciones ${ }^{43}$.

A estos argumentos, hay que sumar el altísimo riesgo que conlleva para el Estado de derecho dejar que la Administración decida libremente y en cada momento qué tipo de reglas son las más adecuadas para regular su actividad ${ }^{44}$ : como es evidente, a menudo, terminará escogiendo disfrutar de las bondades de la autonomía de la voluntad y poco importará si con ello se aparta del principio de legalidad. A este respecto, se ha observado que, en un Estado democrático, "es la legalidad [Art. 103 CE, 209 CN] y no la libertad lo que está en la base misma de la actuación de los poderes públicos ${ }^{945}$. Ahora bien, entendámonos: no se trata de abanderar la prohibición del uso de las instituciones de derecho privado por parte de la Administración: ni las propias constituciones lo hacen. Por el contrario, conscientes de que el interés general suscita, en determinadas ocasiones, la necesidad de acudir a determinadas formas privadas, sólo se trata de aclarar los límites de utilización de esta técnica como "instrumento de actuación en manos [de la Administración] (...) para la gestión de un servicio que es propio de ella misma"46.

En este orden de ideas, el estudio de los entes públicos desde la teoría de la administración instrumental, ha permitido re-encaminar la gran mayoría de entes institucionales estatales formalmente de derecho privado hacía el derecho administrativo. En este sentido, la doctrina ha hecho hincapié en la "artificiosidad"

43 Cfr. García de Enterría, E. and Fernández Rodríguez, T. R., Curso de ... ob.cit.., pág. 407. En la misma línea argumentativa: Martín Navamuel, J., "La gestión tributaria en el nuevo Impuesto de la Renta de Personas Físicas", en Escritos jurídicos en memoria de Luis Mateo Rodríguez, vol. I, Santander, 1993, pág. 288 y ss.

44 Vid: Parejo Alfonso, L., “Ámbito de aplicación y principios generales de la Ley de Régimen Jurídico de las Administraciones públicas y Procedimiento Administrativo Común, " en La nueva Ley de régimen jurídico de las Administraciones públicas y procedimiento administrativo común, Madrid, 1993, pág. 21 y ss.

45 García de Enterría, E. and Fernández Rodríguez, T. R., Curso de ... ob.cit.., pág.409.

46 Idem, 401; En la misma posición: NieTo, A., "La Administración sirve con objetividad a los intereses generales”, en Estudios de la Consitución Española homenaje al Prof. Eduardo García de Enterría, , Madrid, 1991, pág. 2238 y ss; Del SAz Cordero, S., "Desarrollo y criris...", en Nuevas... ob.cit.., pág.178; Ariño Ortíz, G., ¿Privatizar el Estado?... ob.cit.., pág. 55 y STC 14/1986 Ponente. Don Francisco Pera Verdaguer. 
y dependencia de la Administración de este tipo de organismos: por un lado, se observa, "son creados y extinguidos en virtud de simples decisiones de voluntad estatal, autonómica (y paralelamente de los entes locales)" ${ }^{\prime 47}, \mathrm{y}$, por otro, al ser todos ellos fruto de la Administración (dotados de patrimonio propio -compuesto por dineros públicos-, de autonomía financiera y personalidad jurídica), mantienen una relación de dependencia y son constantemente influenciados y controlados por ella.

Para recapitular, tres son los elementos fundamentales en el uso de figuras jurídicas iusprivatistas por parte de la Administración que hemos analizado: las nuevas necesidades de gestión económica en sectores técnicos o especializados (v.gr. los servicios públicos) propios de la Administración que, en busca de "eficacia", pretenden ser suplidas mediante las técnicas propias del mundo empresarial; la creación de entes independientes con patrimonio autónomo y presupuesto propio ("la imputación directa al mismo [ente] de sus ingresos y gastos implica la posibilidad de una excepción al principio de universalidad de los presupuestos generales del Estado"48); y la remisión de la regulación del "ente público" a "estatutos" redactados por la propia Administración, "cuyo contenido les permite apartarse de la generalidad del derecho administrativo y, con ello, del principio de legalidad en la pretensión de adquirir la libertad de los propietarios en la gestión de sus negocios"49.

Dentro del Estado Social y Democrático de Derecho, las ataduras constitucionales de los poderes públicos (entre ellas, servir a los intereses generales, promover la libertad y la igualdad del todas las personas -principio de concurrencia-, sometimiento a las normas presupuestarias por la naturaleza pública de sus fondos etc.) impiden a la Administración Pública el uso indiscriminado o el "abuso" de las formas y normas propias del sector empresarial. En particular, el administrado debe rechazar todo tipo de técnicas que le permitan al Estado "huir" de los rigores propios de su estatuto: el derecho administrativo ${ }^{50}$ Y ello, teniendo presente que la dicotomía principio de legalidad/eficacia de la acción administrativa, contiene una contradicción sólo aparente, ya que una correcta lectura del primer término incluye y no excluye al segundo: y es precisamente la exigencia constitucional (legal) de que la actuación de la Administración pública se rija en todo momento por los principios de eficacia, celeridad y economía que hace problemática la justificación en estos términos del recurso al derecho privado.

47 García de Enterría, E. and Fernández Rodríguez, T. R., Curso de ... ob.cit.., pág.401.

48 Idem pág. 403. "En muchas ocasiones las autonomías financieras resultan con frecuencia más difícilmente justificables y buscan, sencillamente, una huida del derecho presupuestario general, bien en el terreno de los ingresos (...) bien en los controles del gasto (exención al control parlamentario preventivo; excención de los controles simultáneo y sucesivo por la Intervención general de la Administración del Estado (...) Entra pues en juego un abuso de la personalidad jurídica con el fin de alcanzar un régimen especial financiero, caracterizado por una distensión u omisión de rigores)".

49 Ibidem.

50 Cfr. Clavero Arevalo, M., "Personalidad jurídica...", en Documentación... ob.cit. 


\section{Sobre el segundo cuestionamiento. Pautas para la utilización de formas jurídicas privadas por parte de la Administración}

Los estudiosos del derecho administrativo-económico han ofrecido algunas pautas generales para la prudente elección, por parte de los Legisladores y de la Administración, de la forma de organización pública o privada de sus entes instrumentales. Estas pautas, como hemos dicho, no están orientadas a la prohibición del uso de las formas privadas por la Administración, sino a evitar el "abuso" de las herramientas de derecho privado (con particular respecto a las societarias).

\subsection{El servicio público}

El concepto de "Service Public" ha sido uno de los ejes centrales del derecho administrativo desde sus inicios ${ }^{51}$. En doctrina administrativista, se han enfrentado dos diversas posturas sobre la delimitación del concepto de servicio público. La primera $^{52}$, más amplia, parte de la idea de que toda actuación administrativa es una actuación de servicio público, y éste, a su vez, es un medio para el cumplimiento de los fines constitucionales. En este marco, los fines a alcanzar por el Estado vienen predeterminados por la Constitución y son desarrollados por el Legislador. Para el cumplimiento de tales fines, a la Administración (dirigida por el Gobierno), le corresponde la satisfacción de las necesidades de los ciudadanos y tal satisfacción sólo es posible a través de la prestación de los servicios públicos. Siempre dentro de un concepto amplio, otros administrativistas clásicos conciben el servicio público más que como un medio, como una finalidad en sí mismo: "éste es la obra a realizar por la Administración, si bien el poder (puissance publique) es el medio para su realización" $" 53$.

La segunda posición, más restringida y compartida por la mayor parte de la doctrina contemporánea, dentro de la definición de servicio público, contempla no toda la actividad administrativa, sino sólo una parte de ésta. En este sentido, la actividad de la administración está compuesta, por una parte, de aquellas expresiones en las que se ejercitan potestades públicas (denominada "función pública"); por otra, por aquellas actividades materiales, técnicas e industriales puestas a disposición de los particulares ${ }^{54}$ (llamada "servicio público"). Así, la titularidad de la "función pública" le corresponde al Estado mientras que, de la prestación de los "servicios

51 Garrido Falla, F., "El concepto ...", en Revista ..., ob.Cit., pág. 7 y ss.

52 Duguit, L. and Posada, A., Las transformaciones del derecho público, Pamplona, 2006, pág. 93 183.

53 Rivero, J., "Hauriou et l'avènement de la notion de service public", en L'evolution du droit public. Etudes en l'honneur d'Archille Mestre, París, 1956, pág. 461.

54 Zanobini, G., corso di dirito amministrativo, vol. I, Milán, 1958, pág. 27. 
públicos", éste sólo asume su "gestión por razones técnicas, económicas o sociales, pero sin que repugne la idea de su gestión por los particulares"

Resulta de particular ejemplificación la realidad de las funciones de inspección y vigilancia. Como lo hacíamos ver, tradicionalmente estas funciones se han caracterizado por estar adscritas a la clásica función de policía. Hoy, cada vez más, por el alto grado de complejidad técnica y de especialización que las mismas implican, se permite su ejercicio por el sector privado. Este es el caso de materias como la seguridad industrial o el medio ambiente. La Administración, teniendo en cuenta las dificultades que el ejercicio de tales actividades atañe y consciente de sus escasos medios humanos y tecnológicos, opta por delegar a las empresas privadas el desarrollo de las mismas. Queda el interrogante de si, en estos casos, el Estado debe asumir una posición de garante y responsabilizarse del sujeto privado que desempeña este tipo de "funciones públicas" o, si por el contrario, las potestades administrativas (funciones públicas de policía, justicia etc.) en virtud de la salvaguarda de los derechos fundamentales, del mandato de actuación directa de la administración y de su intensa intervención en la esfera de los administrados, deben ser ejercidas exclusivamente a través de procedimientos públicos y estar sujetas a las normas de derecho público. En este mismo sentido, es válido preguntarse si la imposibilidad de la Administración para satisfacer adecuadamente una necesidad pública que implique el ejercicio de poderes autoritarios amplía el espectro de actuación del "sector privado", debido a la posesión, por parte de este último, de los recursos materiales y técnicos para satisfacerla ${ }^{56}$

En estricta observancia de los derechos fundamentales como garantía máxima de los administrados y límite a los poderes públicos, sugiere la doctrina administrativista ${ }^{57}$ que tal vez sea mejor adjudicar la condición de "colaboradores de la Administración" a aquellas entidades reguladas por el derecho privado que tienen a su cargo el cumplimiento de "funciones públicas" y, de esa manera, reconducir sus actos de poder al derecho público.

Otro sector de la doctrina administrativista, profundizando en el criterio estricto de servicio público, ha considerado que dichos servicios comprenden tanto "la actividad administrativa de prestación" como aquella dirigida a la producción y puesta de bienes en el mercado ("actividad administrativa de dación") ${ }^{58}$. Es precisamente en este último sector, que no tiene carácter de "servicio público" en sentido estricto y en el que no se utilizan potestades administrativas exorbitantes, en

55 Garrido Falla, F., "El concepto ...”, en Revista ..., ob.Cit., pág.12.

56 En el mismo sentido se cuestiona García Ruiz, E., La nueva sociedad ... ob. cit., pág.65 y ss.

57 Entre ellos García Torres, J. and Jimenez- Blanco, A., Derechos fundamentales y relaciones entre particulares, Madrid, 1986, y Rivero Ortega, R., Administraciones ... ob. cit., pág. 143.

58 Garrido Falla, F., “El concepto ...”, en Revista ..., ob.Cit., pág.14;Villar Palasi, J. L., "La actividad industrial del estado en el derecho administrativo", en Revista de Administración Pública, Núm.3, 1950, pág. 53-129., García de Enterría, E. and Fernández Rodríguez, T. R., Curso de ... ob.cit.., pág 419. 
donde es constitucionalmente viable la intervención pública mediante la utilización de herramientas jurídico - privadas (sociedades anónimas públicas, sociedades de economía mixta etc. $)^{59}$.

De lo anterior, se colige que el servicio público es "el servicio técnico prestado al público de una manera regular y constante mediante una organización de medios personales y materiales cuya titularidad pertenece a una Administración pública y bajo un régimen jurídico especial" ${ }^{\prime 60}$. De estas notas características, interesa resaltar que, por tratarse de "prestaciones al público", los denominados servicios públicos deben cubrir a todos los administrados (principio de igualdad) y deben ser prestados de "manera regular y continua", lo que justifica una exigencia de servicios mínimos ${ }^{61}$.

Entonces, en aplicación de este criterio, hemos dicho que no le está constitucionalmente permitido a la Administración hacer uso de formas privadas para cumplir con aquella parte de su actividad denominada "función pública". También hemos dicho que la Administración está facultada (lo que no quiere decir obligada) para gestionar, mediante formas jurídico-privadas, su actividad de "dación" (producción y puesta en el mercado de bienes y servicios). El interrogante ahora sería ¿es posible que "la actividad prestadora" de servicios sea gestionada por la administración mediante entes instrumentales apartados de la regulación propia del derecho administrativo?

Como claramente lo explicaba el profesor GARrido Falla, en principio, todos los servicios públicos deberían tener el carácter de esenciales, pero, las constituciones citadas en este trabajo no reservan a la Administración la prestación exclusiva de todos ellos. En virtud del principio de libertad de empresa (Art. $38 \mathrm{CE}, 333 \mathrm{CN}$ ), los particulares pueden gestionar o ser titulares de servicios públicos.

Amén de ello, las normas fundamentales mencionadas dejan en manos del Legislador la definición de lo que, en cada momento, se debe entender por servicios mínimos o esenciales (Art. 28.2 CE, $56 \mathrm{CN}$ ); asimismo, le facultan para que, mediante Ley, reserve al sector público en régimen de monopolio servicios esenciales (Art. 28.2 $\mathrm{CE}, 336 \mathrm{CN})$. En este marco, dejan en manos de los poderes públicos la promoción de las "condiciones de libertad e igualdad del individuo y de los grupos en que se integran (...) la remoción de los obstáculos que impidan o dificulten su plenitud y la garantía de la participación de todos los ciudadanos en la vida política, económica, cultural y social" (Art. 9.2 CE, 2 CN). En la misma línea, los poderes públicos deben garantizar el derecho a la educación (Art. 27.1CE, $67 \mathrm{CN}$ ), la protección social, económica y jurídica de la familia (Art. 39.1 CE, $42 \mathrm{CN}$ ), la formación y readaptación de los profesionales, seguridad e higiene laboral (Art. $40.2 \mathrm{CE}, 54 \mathrm{CN}$ ), el derecho

59 Cfr. Garrido Falla, F., "El concepto ...”, en Revista ..., ob.Cit., pág.14.

60 Idem, pág. 21

61 El mantenimiento de lo servicios mínimos es un límite constitucional del derecho de huelga (Art. $56 \mathrm{CN}, 28.2 \mathrm{CE})$ 
a la salud (Art. 43.1CE, $49 \mathrm{CN}$ ), el régimen de seguridad social (Art.41 CE, $64 \mathrm{CN}$ ), el disfrute y la conservación del medio ambiente sano (Art. $45.1 \mathrm{CE}, 79 \mathrm{CN}$ ), la protección de los recursos naturales (Art. 45.2CE, $80 \mathrm{CN}$ ), la protección de la tercera edad (Art. $49 \mathrm{CE}, 46 \mathrm{CN}$ ). Amén de ello, las necesidades generales se satisfacen mediante la prestación de los servicios, para lo que se atribuye a la Administración la gestión de los servicios públicos necesarios para la satisfacción de los intereses generales (Art. 97 y $103 \mathrm{CE}, 365 \mathrm{CN}$ ).

Las anteriores bases constitucionales nos sirven para afirmar que los servicios públicos esenciales (incluyendo dentro de ellos obligatoriamente los servicios públicos asistenciales ${ }^{62}$ ) así definidos por el Legislador, independientemente de su prestación en régimen de concurrencia, deben ser prestados por el "sector público" a los administrados sin menoscabo de sus garantías, lo que parece conllevar el uso de formas de derecho público $\mathrm{y}$, por lo tanto, del régimen de derecho administrativo. Recordando, eso sí, que, en todo caso, cuando la Administración no actúe en régimen de monopolio, deberá someterse a la normativa sobre la libre y leal competencia. ${ }^{63}$

No obstante todo lo anterior, "la organización administrativa actual, que se mantiene en línea reductora del Estado y, nuevamente, en busca de eficacia y de mayor dinamismo que aquel que le ofrecen los procedimientos administrativos, tiende a manifestar su preferencia por el principio de subsidiaridad en cuanto a la actividad económica de la administración (cubrir aquellos sectores en los que el empresario no se arriesga, prestar los servicios públicos en defecto de prestación privada)" $" 64$

Dicho ello, el problema se traslada ahora a la regulación mixta y ad hoc de los entes instrumentales de la Administración sometidos al derecho privado. Dichas entidades, en todo caso, están sujetas en su creación, formación de la voluntad, constitución, organización (adquisición y enajenación de acciones, orientación general de sus fines, modificación de estatutos etc.) y extinción al régimen de derecho público, mientras que, en sus relaciones para con terceros, se remiten a lo que preceptúan sus propios estatutos (derecho privado). Esta situación, por un lado, se manifiesta frente al ciudadano como de absoluta inseguridad jurídica (siempre en detrimento de

62 Es decir, "aquellos que garantizan el derecho del administrado a la conservación de la vida, la salud y el desarrollo de la personalidad" v.gr. salud, educación. Cfr. Garrido Falla, F., "El concepto ...", en Revista ..., ob.Cit., pág. 22 y ss.

63 Idem, pág.24 y ss. Asimismo, García Ruiz, E., La nueva sociedad ... ob. cit., pág. 61“ la coexistencia de empresas públicas con fines empresariales y de empresas privadas en el marco de una economía de mercado (...) exige que se garantice y salvaguarde la libre competencia y, para ello, han de regir las mismas reglas para ambos sectores de producción pública y privada. Por tanto, las empresas públicas que actúen en el mercado se han de someter a las mismas cargas sociales, fiscales, financieras y de toda índole que afecten a las privadas, y a sus mismos riesgos, sin poder gozar de privilegios de ningún tipo, pues ello podría impedir, restringir o falsear el juego de la libre competencia del mercado".

64 García Ruiz, E., La nueva sociedad ... ob. cit., pág. 26. 
sus garantías constitucionales) $\mathrm{y}$, por otro, permite evidenciar que tampoco ha sido suficiente para la satisfacción de las necesidades de la Administración la regulación privada. Sobre este problema haremos algunas anotaciones en el siguiente acápite de este trabajo.

Aunque el estudio de este primer criterio nos ha permitido abordar aspectos propios de otras pautas a seguir como el uso de las formas públicas para el ejercicio de potestades administrativas, del poder público (como autoridad) y la diferenciación entre actividades de autoridad y actividades económicas de la Administración, hemos de hacer algunas anotaciones separadamente sobre las mismas.

\subsection{El uso de la "forma pública" para el ejercicio de potestades strictu sensu administrativas por la Administración.}

Este segundo criterio tiene como fundamento diferenciador el tipo de actividad o función que desarrolla el ente instrumental. Cuando, para el cumplimiento de las funciones, la entidad pública precisa hacer uso de autoridades o ejercer potestades propias de los "poderes públicos", es determinante que la misma sea creada y que se regule por normas del derecho administrativo (Art. 15 Ley 30/92 ${ }^{65}$, Art.

65 “1. La realización de actividades de carácter material, técnico o de servicios de la competencia de los órganos administrativos o de las Entidades de derecho público podrá ser encomendada a otros órganos o Entidades de la misma o de distinta Administración, por razones de eficacia o cuando no se posean los medios técnicos idóneos para su desempeño. 2. La encomienda de gestión no supone cesión de titularidad de la competencia ni de los elementos sustantivos de su ejercicio, siendo responsabilidad del órgano o Entidad encomendante dictar cuantos actos o resoluciones de carácter jurídico den soporte o en los que se integre la concreta actividad material objeto de encomienda. 3. La encomienda de gestión entre órganos administrativos o Entidades de derecho público pertenecientes a la misma Administración deberá formalizarse en los términos que establezca su normativa propia y, en su defecto, por acuerdo expreso de los órganos o Entidades intervinientes. En todo caso el instrumento de formación de la encomienda de gestión y su resolución deberá ser publicado, para su eficacia en el Diario oficial correspondiente. Cada Administración podrá regular los requisitos necesarios para la validez de tales acuerdos que incluirán, al menos, expresa mención de la actividad o actividades a las que afecten, el plazo de vigencia y la naturaleza y alcance de la gestión encomendada. 4. Cuando la encomienda de gestión se realice entre órganos y Entidades de distintas Administraciones se formalizará mediante firma del correspondiente convenio entre ellas, salvo en el supuesto de la gestión ordinaria de los servicios de las Comunidades Autónomas por las Diputaciones Provinciales o en su caso Cabildos o Consejos insulares, que se regirá por la legislación de Régimen Local. 5. El régimen jurídico de la encomienda de gestión que se regula en este artículo no será de aplicación cuando la realización de las actividades enumeradas en el apartado primero haya de recaer sobre personas físicas o jurídicas sujetas a derecho privado, ajustándose entonces, en lo que proceda, a la legislación correspondiente de contratos del Estado, sin que puedan encomendarse a personas o Entidades de esta naturaleza actividades que, según la legislación vigente, hayan de realizarse con sujeción al derecho administrativo". 
5 Ley 489/9866). A contrario sensu, la anterior regla llevaría a pensar que, en principio, si el ente administrativo instrumental no necesitare para el ejercicio de su actividad hacer uso de potestades o prerrogativas propias de la Administración, podrá permitírsele ser regulado por el derecho privado.

"Las personificaciones para actuar en régimen privado pueden justificarse cuando la administración pretende actuar en el mercado libre y a nivel de los demás empresarios ejercitando un tráfico en masa de naturaleza materialmente mercantil, carece, sin embargo, de toda justificación posible en otro caso y ni el Legislador, ni menos aún la Administración, pueden dispensar a una organización inequívocamente pública (por su origen, por su actuación, dominada totalmente por la Administración pública matriz, pero su financiación, en cuanto que opera con dinero público procedente de ingresos de ese carácter) de las vinculaciones que la constitución le impone" ${ }^{97}$. En este sentido, sólo es constitucionalmente viable la utilización de herramientas de derecho privado por la Administración para la gestión de servicios públicos de contenido económico.

\subsection{El poder público}

Este tercer criterio nos sitúa sobre posición de superioridad que siempre ha de ser ejercida por la Administración como poder público. Allí donde se localice un ente instrumental que ocupe una superioridad material semejante a la de la Administración y utilice medios que no se encuentran al alcance de los particulares nos enfrentamos a un "poder público". Si la Administración decide gestionarse mediante instituciones de derecho privado y, en tal gestión, se encuentran manifestaciones de "poder público" será preciso introducir normas de derecho público. No debe limitarse la búsqueda de la noción de "poder" a las clásicas potestades de la Administración; ésta se debe hacer extensiva a cualquier actividad administrativa mediante la cual el ente instrumental esté en capacidad de ejercer una posición de superioridad frente a los particulares. En estos casos, será recomendable el uso de formas de derecho público, ya que las de derecho privado no son garantía suficiente para los derechos de los administrados frente a la propia Administración ${ }^{68}$.

66 "Los organismos y entidades administrativos deberán ejercer con exclusividad las potestades y atribuciones inherentes, de manera directa e inmediata, respecto de los asuntos que les hayan sido asignados expresamente por la ley, la ordenanza, el acuerdo o el reglamento ejecutivo. Se entiende que los principios de la función administrativa y los principios de coordinación, concurrencia y subsidiariedad consagrados por el artículo 288 de la Constitución Política deben ser observados en el señalamiento de las competencias propias de los organismos y entidades de la Rama Ejecutiva y en el ejercicio de las funciones de los servidores públicos".

67 García de Enterría, E. and Fernández Rodríguez, T. R., Curso de... ob.cit.., pág. 408.

68 Sobre la noción de "poderes públicos" y posición de superioridad de la Administración Pública: SSTC 35/1983, de 11 de mayo Ponente: Don Francisco Rubio Llorente y 185/1995, de 14 de diciembre Ponente: Don Carles Viver Pi-Sunyer. 
En este sentido, resultan acertadas la referencia al Art. 2.2 Ley 30/92 española "Las entidades de derecho público con personalidad jurídica propia vinculadas o dependientes de cualquiera de las Administraciones Públicas, tendrán, asimismo, la consideración de Administración pública". La misma norma extiende su regulación al "ejercicio de las potestades administrativas" por parte de dichas entidades, y al Art. 5 Ley 489/98 colombiana "Los organismos y entidades administrativos deberán ejercer con exclusividad las potestades y atribuciones inherentes, de manera directa e inmediata, respecto de los asuntos que les hayan sido asignados expresamente por la ley, la ordenanza, el acuerdo o el reglamento ejecutivo". Aunque estos artículos non mencionen, expresamente, a las sociedades públicas reguladas por el derecho privado, por su condición de "poderes públicos" les son aplicables dichas disposiciones y, en este sentido, también los principios de derecho administrativo.

En virtud del marco constitucional que hemos venido describiendo, la condición de "poder público" impide que la Administración se aparte del principio de legalidad y goce de los beneficios de la autonomía de la voluntad. "Los particulares pueden crear empresas con plena libertad de criterios, sin más condición que la de que sus fines sean lícitos (Art. $38 \mathrm{CE}$ ). Por el contrario, todas las actuaciones de los órganos de la Administración pública deben responder al interés público que, en cada caso y necesariamente, siempre ha de concurrir (Art. 103.1 CE), tanto si se trata de actuaciones de autoridad, como de actuaciones empresariales, pues, en cuanto a estas últimas, se les exige una equitativa asignación de recursos públicos y que su programación y ejecución responda a criterios de eficacia y economía, lo cual no es compatible con actuaciones empresariales públicas carentes de justificación" ${ }^{69}$.

\subsection{Distinción, dentro de una misma actividad material y técnica, entre} funciones de autoridad y actividades económicas

Dentro de una misma actividad material y/o técnica a ejercerse por la Administración Pública, un cuarto criterio nos lleva a diferenciar entre aquellas actividades de carácter económico (de mera gestión) prestadas en régimen de concurrencia y aquellas otras que carecen de dicho carácter económico (v.gr. las actividades de ordenación, control, inspección, vigilancia, sanción). Mientras las primeras pueden estar sometidas al régimen de derecho privado, las segundas (prerrogativas del poder público) solamente podrán regularse por normas de derecho público. La asignación de actividades propias del "poder público" a empresas públicas reguladas por el derecho privado colocaría a estas últimas en una posición dominante en el mercado ${ }^{70}$.

69 García Ruiz, E., La nueva sociedad ... ob. cit., pág.71.

70 Cfr. Muñoz Machado, S., Público y privado en el mercado europeo de la TV, Madrid, 1993, y Rivero Ortega, R., Administraciones ... ob. cit., pág. 144 y ss. 


\section{La empresa pública como manifestación típica de la "huida del derecho administrativo". Criterios o pautas para determinar su naturaleza real.}

Diversos entes autónomos con personalidadjurídica, patrimonio propioy remitidos, para su regulación, al derecho privado son utilizados por la Administración pública para dar cumplimiento a sus fines constitucionales. Dentro de la multiplicidad de las instituciones jurídico-privadas utilizadas por la Administración, la más recurrida es la sociedad anónima de capital público o mixto. Determinar la naturaleza real (pública o privada) de las sociedades mercantiles de capital totalmente público o de aquellas participadas por dineros públicos no ha sido tarea fácil para los estudiosos del derecho Administrativo y Mercantil. En este sentido, la legislación, la jurisprudencia y la doctrina han desarrollado algunas pautas:

\subsection{La personalidad jurídica}

Así como, a mediados del siglo XIX, se garantizó la autonomía del "Estado" mediante el reconocimiento de su personalidad jurídica, la Administración pública concibe organizaciones personificadas con la finalidad de asegurar que "las relaciones jurídicas necesarias para la gestión del servicio concluyan en la propia organización y no se transfieran a la Administración matriz"71 y de disfrutar de autonomía administrativa y presupuestal para el cumplimiento de determinadas funciones a su cargo. Por otra parte, si bien es cierto que determinadas sociedades mercantiles participadas por dineros públicos pueden, por disposición legal apartarse -al menos formalmente- del principio de jerarquía y de unidad de patrimonio público, también lo es que las mismas entidades con personalidad jurídica pueden quedar vinculadas al principio de unidad administrativa (Art. 38 Ley 489/98 - Art. 2.2 ley 30/92) y, por ende, sometidas al de jerarquía. Así las cosas, este criterio por sí solo, no parece ser suficiente para determinar la verdadera naturaleza de las sociedades anónimas públicas.

71 García de Enterría, E. and Fernández Rodríguez, T. R., Curso de ... ob.cit.., pág.402 Sobre el criterio de la personalidad jurídica: García DE ENTERRÍA, E., "El concepto de pesonalidad jurídica en el derecho público", en Administración Instrumental. Libro homenaje a Manuel Francisco Clavero Arévalo, vol. II, Madrid, 1994, pág. 829-836; Boquera Oliver, J. M., "La sistematización del derecho administrativo desde la personalidad jurídica de la Administración del Estado", en Administración Instrumental. Libro homenaje a Manuel Francisco Clavero Arévalo, vol. II, Madrid, 1994, pág. 841 y ss.; Lafuente Benachez, M., "Las nociones de Administración Pública y personalidad jurídica", en Administración Instrumental. Libro homenaje a Manuel Francisco Clavero Arévalo, Madrid, 1994, pág. 962 y ss.; Esteve Pardo, J., "La personalidad jurídica en el derecho público y la dialectica Estado-sociedad. Prespectiva histórica”, en Administración Instrumental. Libro homenaje a Manuel Francisco Clavero Arévalo, Madrid, 1994, pág. 879 y ss. 


\subsection{La propiedad del capital}

Tradicionalmente, las legislaciones han entendido por sociedades mercantiles estatales aquellas cuyo capital se compone en un $100 \%$ de dineros públicos o aquellas en las que, por lo menos el $50 \%$ de su capital es público (es decir, perteneciente a la Administración y/o a cualquiera de sus organismos públicos) ${ }^{72}$. Ello no obstante, las nuevas legislaciones empiezan a incorporar otras pautas para la determinación de la naturaleza de las sociedades participadas por el Estado ${ }^{73}$.

El criterio de la propiedad del capital se ha visto superado por la realidad de la empresa pública. Bajo su lupa, ¿Qué naturaleza tendrían aquellas sociedades en las que el Estado es sólo un socio minoritario, pero cuyos órganos de decisión resultan controlados por la Administración Pública? Y lo mismo cabría preguntarse respecto de aquellas sociedades de capital público minoritario fuertemente reguladas por normas de derecho público. Siguiendo este criterio, sería válido afirmar que no se podrían catalogar como públicas aquellas empresas en las cuales el porcentaje de participación pública es mínimo, no obstante exista un fuerte interés de la Administración por ejercer su control mediante los instrumentos normativos a su alcance. Esta situación ha dejado entrever la insuficiencia del criterio de "la propiedad del capital" si se utiliza como única pauta para la determinación de la naturaleza pública o privada de una sociedad participada por dineros públicos.

\subsection{La forma jurídica utilizada}

En el primer acápite de este trabajo, decíamos que la Administración Pública está facultada para organizarse de diversas formas y que, por ello, hace uso de figuras propias tanto del derecho público como del derecho privado, remitiendo la regulación de sus instituciones a normas de derecho público o derecho privado según corresponda. Así mismo, decíamos que, de una lectura sistemática de las disposiciones constitucionales estudiadas, parece desprenderse la exigencia de utilización de formas públicas para el ejercicio de las denominadas "funciones públicas" y para la llamada "actividad prestadora de servicios esenciales", mientras que se deja a la discrecionalidad de la Administración la elección de la forma pública o privada para la prestación de las actividades puramente económicas o de "dación". Ello no obstante, la realidad administrativa que se presenta hoy se muestra colmada de diversas y dispersas formas organizativas con regulaciones, en la mayoría de los casos, mixtas. Lo anterior impide que este criterio, aunque completo y ciertamente indicativo, pueda ser suficiente para determinar la naturaleza pública de una empresa.

72 El parágrafo del Art.38 de la Ley 489/98 determina una propiedad de capital estatal del $90 \%$ o más: "Las sociedades públicas y las sociedades de economía mixta en las que el Estado posea el noventa por ciento $(90 \%)$ o más de su capital social, se someten al régimen previsto para las empresas industriales y comerciales del Estado".

73 Es el caso de la Ley 33/2003 de Patrimonio de las Administraciones Públicas (España). 


\subsection{El control público}

La utilización de formas societarias por parte de los poderes públicos, las dificultades para armonizar el interés general con el interés social y la insuficiencia de las normas estrictamente privadas para la regulación de las sociedades anónimas de capital público o mixto, ha llevado a la doctrina a interrogarse acerca de la posibilidad de determinar la naturaleza pública o privada de las mismas de acuerdo con el grado del control ejercido por la Administración Pública ${ }^{74}$.

En este marco, se ha observado que, independientemente de la forma jurídica (pública/privada) que adopten las empresas participadas con capital público, parecería ser que, al Gobierno (cabeza de la Administración), le cuesta desprenderse del control político y de la gestión administrativa que sobre ellas está acostumbrado a ejercer.

Como consecuencia de ello, el balance actual arrojado por las sociedades anónimas de capital público o mixto es desalentador: desplazamiento de objetivos económicos (inherentes a la sociedad) por objetivos políticos (del Gobierno), situación que termina reflejándose en la escasa rentabilidad de la empresa; eliminación del riesgo empresarial propio del derecho societario (con las constantes inyecciones de capital estatal); dilución de la responsabilidad sus administradores (en su mayoría, políticos); interferencias políticas en el nombramiento de los directivos de estas empresas contraviniendo las exigencias técnicas y económicas propias de este tipo de actividades; inseguridad como consecuencia de la regulación mixta a la que se someten este tipo de entidades; pérdidas contables (y ciudadanos como destinatarios finales de dichas deudas); en general, menoscabo a la libre competencia ${ }^{75}$.

Ante la situación descrita, surgen demandas de la doctrina mercantilista que han ejercido una fuerte presión para que el denominado "sector público" no sólo adopte formas de derecho privado cuando pretenda intervenir en el mercado, sino que, además, se dote de una real autonomía financiera (frente a los presupuestos generales del Estado) y, sobre todo, de una mayor autonomía en el los procesos de toma de decisiones que evite cualquier tipo de intervención política en el sector empresarial.

No obstante lo anterior, conviene no olvidar que, para la Administración pública, el régimen societario privado se ha mostrado insuficiente para el cumplimiento de sus fines económicos y sociales, lo que ha dado lugar a la creación - o al

74 Y sobre la viabilidad de creación de un régimen jurídico especial o incluso de una institución específica para el cumplimiento de los cometidos económicos de la Administración.

75 García Ruiz, E., La nueva sociedad ... ob. cit., pág.29 “Creándose muchas veces una inexistente obligación estatal de resolver permanentemente todos los problemas de sus empresas lo que es incompatible con la exigencia permanente de adaptación a las exigencias de mercados globales y competitivos”. En el mismo sentido: Girón Tena, J., Derecho de Sociedades, Madrid, 1976, pág.95 y ss. 
mantenimiento - de un "derecho mixto" regulador de las sociedades anónimas públicas -una normativa que ha necesitado de la integración de normas de derecho administrativo en aras de excluir o exceptuar algunos aspectos del régimen privado de las sociedades anónimas-.

Como consecuencia de ello, en la actualidad, el régimen jurídico de las sociedades de capital público o mixto no sigue fielmente lo establecido para las sociedades anónimas privadas. El mismo se ha ampliado, sustituido $\mathrm{y}$, en general, se ha cambiado, con la finalidad de dar cabida a los intereses públicos y satisfacer las necesidades coyunturales de descentralización y autonomía pretendidas por la Administración Pública.

Lo dicho, además de crear un panorama de inseguridad jurídica en la materia, ha permitido una duplicación de los mecanismos de control ejercidos por parte de la Administración sobre estas instituciones societarias: por un lado, el inherente a toda sociedad privada; por otro, el que se desarrolla por los cauces propios del derecho Administrativo.

Teniendo en cuenta todo lo anterior y haciendo eco de lo que ya venía diciendo la doctrina, la nueva tendencia legislativa (v.gr. disposición duodécima de la Ley 33/2003, de Patrimonio de las Administraciones Publicas española), para calificar la sociedad anónima participada por dineros públicos como sociedad pública, integra en sus preceptos otro criterio independiente del porcentaje de participación en el capital social: el control ejercido por la Administración en la Sociedad. Con apoyo en este criterio, podrán clasificarse como públicas sociedades anónimas de capital minoritariamente público pero controladas por la Administración pública.

Ahora bien, una vez enunciado el criterio general, queda por aclarar qué grado de presencia de los poderes públicos es necesario para afirmar que la sociedad es controlada por ellos y, por ende, que es pública.

Para resolver el interrogante, el derecho comunitario toma en consideración el concepto de influencia dominante: mientras la influencia de la Administración no deje de ser dominante, la empresa, independientemente de la forma jurídica utilizada o de la propiedad del capital, deberá ser considerada pública (directiva 80/723/CEE, de 25 de junio de 1980, Directiva 85/413/CEE, de 24 de julio de 1985, Directiva 90/531/CEE de 17 de septiembre de 1990, Directiva 93/38/ CEE, de 14 de junio de 1993). En la última directiva mencionada, se aclara que la influencia dominante ha de presumirse toda vez que los poderes públicos posen la mayoría del capital suscrito en la empresa, disponen de la mayoría de votos o puedan designar a la mitad de los miembros del órgano de administración. Lo anterior, a efectos de salvaguardar la libre competencia, evitar la dispersión de responsabilidades de los miembros del consejo de administración, el abuso de la utilización discrecional de las formas jurídicas de la empresa pública y la alteración del principio de paridad de trato ${ }^{76}$.

76 Cfr. García Ruiz, E., La nueva sociedad ... ob. cit., pág. 52 y ss. 
En esta misma línea, la jurisprudencia española ha aceptado que la presencia de la Administración en la empresa es innegable toda vez que la creación, formación de la voluntad, constitución, organización (adquisición y enajenación de acciones, orientación general de sus fines, modificación de estatutos etc.), extinción y control están sometidos a un régimen de derecho público todo lo anterior hace presumir una disposición de la Administración pública para ejercer el control sobre la empresa, disposición que se considera equivalente al ejercicio efectivo del control mismo y, por ende, condición suficiente para afirmar la naturaleza pública de la entidad ${ }^{77}$. Por su parte, la legislación colombiana (Art. 38 y ss. Ley 489/1998) mantiene la propiedad del capital social como único criterio clasificatorio del régimen aplicable $\mathrm{y}$, por lo tanto, definitorio de la naturaleza pública o privada de la entidad.

Aclarado lo anterior, doctrina y jurisprudencia ${ }^{78}$ han formulado criterios que permiten inducir la existencia de un control efectivo de los poderes públicos sobre la sociedad participada, a saber:

- mediante la creación del ente.

- A través de la propiedad mayoritaria del capital social.

- La disposición de la mayoría de los votos inherentes a las participaciones emitidas.

- La facultad, prevista por el estatuto, para controlar el órgano de Administración, de dirección o de vigilancia designando más de la mitad de sus miembros.

- La relación de los presidentes del órgano de administración con la Administración pública.

- La integración de los presupuestos de la sociedad mercantil en los presupuestos generales del Estado.

- La posibilidad de que la Administración pública ejerza el control sobre la contabilidad de la empresa.

- La posibilidad de que la Administración pública modifique la actividad empresarial mediante normativa general o específica, o la posibilidad de suspender una decisión de la empresa.

- $\quad$ La posibilidad para la Administración de ejercer el control mediante normas administrativas de regulación de la empresa.

- La posibilidad para la Administración de introducir normas especiales dentro del régimen jurídico general al que remite la regulación de la sociedad.

- La posibilidad para la Administración de incidir de manera directa o

77 Idem, pág. 60 "Lo decisivo en el criterio de control no es que la Administración influya sino que tenga la posibilidad de influir en la gestión cotidiana de la empresa".

78 STC 177/2002, de 14 de octubre Ponente: Don Manuel Jiménez de Parga y Cabrera 
indirecta en la formación de la voluntad de la empresa o en su gestión.

- La posibilidad para la Administración de incidir mediante las técnicas de control que le proporciona el derecho administrativo en los resultados de la empresa.

- La posibilidad para la Administración de controlar el cumplimiento de los objetivos o compromisos adquiridos por la empresa (control de la eficacia).

Así entendido, el control público como criterio para determinar la naturaleza pública de la entidad es perfectamente aplicable a las sociedades mercantiles públicas o mixtas, aún cuando su gestión esté remitida al derecho privado. Que la creación, formación de la voluntad, la normativa presupuestaria y contable, el control financiero y la contratación estén sometidos al derecho público (es decir, que la regulación de las sociedades públicas tenga un carácter mixto) hace suponer (lo que no resulta baladí) cierta influencia de los poderes públicos sobre la gestión política y económica de la empresa. Y, como hemos visto, dicha suposición, en tanto en cuanto configura una posibilidad de control, resulta por sí misma suficiente para concluir por la naturaleza pública de la entidad.

La práctica ha debilitado los criterios tradicionales para la clasificación como públicas o privadas de las empresas participadas por dineros públicos. Para considerar como pública una sociedad, ya no es suficiente la utilización separada de criterios como la creación de entidades con personalidad jurídica, la titularidad de la mayoría de capital social, la realización de actividades propias del sector privado, la utilización de formas propias del sector privado o la remisión tout court de los estatutos al régimen societario privado. Todas las pautas arriba analizadas, hoy forman parte de la casuística del criterio general del control por parte de los poderes públicos sobre las sociedades, participadas o no por dineros públicos ${ }^{79}$.

\section{Controles sobre la elección de la Administración de actuar bajo formas de derecho público o de derecho privado.}

Como toda actuación dentro del Estado Social de Derecho, la intervención del Estado en la economía a través de la creación de empresas públicas o privadas y la potestad organizadora de la Administración, a pesar de su carácter discrecional, están sujetas a controles tanto administrativos (Contraloría - Tribunal de Cuentas)

79 No obstante en este trabajo hayamos limitado el análisis a las sociedades participadas por dineros públicos, lo cierto es que el criterio del control ofrece interesantes aplicaciones incluso en las sociedades con capital enteramente privatizado. En este sentido: GARcía Ruiz, E., La nueva sociedad ... ob. cit., pág.75 y ss; Montoro Romero, C., "La privatización entre la crisis del Estado de bienestar y la crisis de identidad de la empresa pública”, en Economistas, Núm.19, 1986, pág. 25 -31, Piñar Mañas, J. L., "Privatización de la empresa púlica y Derecho Comunitario", en Revista de Administración Pública, Núm. 133, 1994, pág. 18 y ss, Rodríguez-Arana MuÑoz, J., La privatización de la empresa pública, Madrid, 1991, 
como jurisdiccionales (Tribunal/Corte Constitucional - Tribunales contenciosoadministrativos).

El control constitucional de la intervención del Estado en la economía y, en particular, de la elección de instrumentos de derecho público o privado para llevar a cabo dicha intervención, ha sido entendido por la Corte Constitucional colombiana como "un escrutinio constitucional más dúctil, precisamente para respetar principios de raigambre constitucional, como la separación de poderes, la libertad de configuración del legislador, la participación democrática, el pluralismo y la autonomía de los particulares" $"$. Asimismo, en la sentencia C-265 de 1994, la Corte precisó que: "el juez constitucional debe actuar de manera prudente al analizar la legitimidad constitucional de una determinada regulación de las libertades económicas, por cuanto la Constitución consagra la dirección de la economía por el Estado. El juez constitucional deberá entonces respetar en general las razones de conveniencia invocadas por los órganos de representación política. La Corte considera que en esta materia se impone el llamado criterio de la inconstitucionalidad manifiesta, por lo cual, sólo si de manera directa la norma vulnera derechos fundamentales, o viola claros mandatos constitucionales, o incurre en regulaciones manifiestamente irrazonables o desproporcionadas, deberá el juez declarar la inconstitucionalidad de la norma. Es decir, si la ley que regula la actividad de sociedades de contenido patrimonial no vulnera claramente la carta fundamental o establece regulaciones manifiestamente irrazonables debe ser considerada constitucional, por cuanto hay cláusulas generales que autorizan la intervención estatal en la economía".

Por el contrario, el Tribunal Constitucional español ha mantenido una interpretación más estricta a la hora de valorar la elección de la Administración de emplear entidades sometidas al derecho privado. Los jueces constitucionales españoles han observado que, en la cotidianidad, "ha adquirido (...) carta de naturaleza la creación por la Administración de entes institucionales bajo formas privadas de personificación, muy en particular, bajo la forma de sociedades anónimas, lo que conduce a la actuación bajo un régimen de derecho privado, de entes que se han personificado bajo una forma jurídica pública, de todo lo cual es buena muestra la misma ley de sociedades anónimas que (...) admite sociedades de este tipo con un solo accionista, un ente público (...)". Pacífico lo anterior, los magistrados llaman la atención sobre el hecho que, no obstante las apariencias, "la instrumentalidad de los entes que se personifican o que funcionan de acuerdo con el derecho privado, remiten su titularidad final a una instancia administrativa inequívocamente pública, como público es también el ámbito interno de las relaciones que conexionan dichos entes con la Administración de la que dependen, tratándose en definitiva de la utilización por la Administración de técnicas ofrecidas por el derecho privado, como un medio práctico de ampliar su acción social y económica (...)”. De ahí que

80 Sentencia C-093 de 2001 Ponente: Alejandro Martínez Caballero. 
suena casi descontada su conclusión: "La forma mercantil supone la introducción en el tráfico de una entidad que externamente, en sus relaciones con terceros, va a producirse bajo un régimen de derecho privado, pero internamente tal sociedad es realmente una pertenencia de la Administración, que aparece como socio exclusivo de la misma, un entre institucional propio de la misma, y a estos conceptos responde la regulación legal española"81.

Con el objeto controlar la base de legalidad del actuar de la Administración en el ejercicio de su potestad de organizarse y en el funcionamiento de las entidades por ella creadas, la Jurisdicción Contencioso-administrativa española realiza un control que se caracteriza, en general, por aplicar las técnicas de control de las potestades discrecionales ${ }^{82}$. En particular, el Juez administrativo ha recurrido a la utilización de la técnica de los actos separables y la doctrina del levantamiento del velo.

La aplicación de la técnica de los actos separables ha permitido considerar como "administrativos" los actos (procedentes de la Administración) de creación de la entidad (que se regirá por normas de derecho privado) y todas las instrucciones de dirección que resulten determinantes para su gestión. Tales actos ("perfectamente separables de la actuación jurídico - privada del ente" ${ }^{\text {"83 }}$ ) se someten a normas de derecho administrativo y, por ende, al control de la Jurisdicción contenciosa.

En esta misma línea, la implementación judicial de la doctrina del levantamiento del velo ha permitido "localizar al titular real por debajo de la vestidura de una personificación jurídica abusiva con la que se pretende defraudar la Ley o a los terceros" "84. Ejemplo de ello, son los casos planteados en la SAP de Gipuzcuoa de 25 de octubre de $1999^{85}$ y en la STS 22 de septiembre de $1995^{86}$. En ambos casos, se cuestiona el carácter público de fundaciones creadas por la Administración

81 STC 14/1986 Ponente: Don Francisco Pera Verdaguer. En la misma línea STC 54/1994 Ponente: Don Luis López Guerra: “cuando la Administración ostenta un dominio total sobre un entre y éste se encuentra además en una posición privilegiada con respecto a la que ocupan los sujetos privados, su organización en forma mercantil esconde su verdadera naturaleza”.

82 Mediante las técnicas de control de los actos discrecionales dirigidas a los elementos reglados, los hechos determinantes y los principios generales del derecho.

83 García de Enterría, E. and Fernández Rodríguez, T. R., Curso de ... ob.cit., pág.410. y del Tomo II pág. 606 y ss. al acuñar el término de "núcleo público" para todos los casos en que la Administración hace uso del derecho privado "es preciso siempre distinguir entre la decisión de actuar, que es siempre decisión pública en cuanto procedente de una entidad perteneciente al aparato organizativo global de la Administración Pública y que, en consecuencia, debe ser enjuiciada a la luz de los principios generales del ordenamiento jurídico- administrativo por los Tribunales de la jurisdicción contencioso-administrativo".

84 Idem, pág.409.

85 Ponente: IIlma. Sra. coro cillán garcía de yturrospe

86 Ponente: Excmo. Sr. Antonio Nabal Recio En el mismo sentido: SSTS de 3 de julio de 1991, 31 de Julio de 1992 y 20 de febrero de 1995. En sentido contrario: Sentencia de la Audiencia Provincial de Barcelona 17 de septiembre de 2001 Ponente: IIlma. Sra. María Nuria Zamora Pérez. 
Local, dotadas -en sus actos de creación- de personalidad jurídica, capacidad para contratar y autonomía funcional de carácter operativo, pero dependientes en sus finanzas del presupuesto municipal y cuyos órganos de gobierno estaban formados por miembros de las corporaciones locales. Estas razones permitieron al Juez administrativo reafirmar la relación entre Administración creadora y entidad creada $\mathrm{y}$, con independencia de la naturaleza "formalmente" privada de esta última, hacer responsable -subsidiariamente- a las Administraciones Locales de las deudas impagas por las Fundaciones.

\section{CONCLUSIONES}

- En las páginas anteriores, hemos hecho hincapié en la importancia de la definición del derecho administrativo como derecho estatutario de la Administración Pública, de la función del Estado como director de la economía y de la Administración Pública como titular de la potestad organizatoria. Partiendo de dichas premisas, hemos abordado el estudio de las limitaciones constitucionales existentes para el uso del derecho privado por parte de la Administración dentro del Estado Social de Derecho. En particular, se ha evidenciado que dichos límites deben ser observados cuando, como consecuencia de la utilización por parte de la Administración de formas jurídicas iusprivatistas, resulte un menoscabo de las garantías de los administrados o bien ante la imposibilidad de dar cumplimiento a las finalidades constitucionales encomendadas a la Administración.

- Dando por sentado que el Estado está facultado para actuar como agente económico en cualquier sector de la economía mediante la utilización de los instrumentos públicos o privados idóneos para el cumplimiento de sus fines, la atención se centra en las razones que llevan a la Administración Pública a recurrir a figuras propias del derecho privado. En esta línea, hemos resaltado que: de una parte, causas como la multiplicidad de fines constitucionales asignados a la Administración dentro del Estado Social de Derecho -en particular, la asunción de actividades de carácter comercial e industrial y de prestación de servicios asistenciales- y, de otra parte, la creencia generalizada de que tales fines no han sido completamente satisfechos mediante la utilización de formas iuspublicistas, han dado origen a la búsqueda incesante de formas jurídicas ágiles, flexibles ,"eficientes” y libres de los rígidos controles del derecho administrativo.

- No obstante lo anterior, las ataduras constitucionales de los poderes públicos (v.gr. servir a los intereses generales, promover la libertad e igualdad de todas las personas, sometimiento a las normas presupuestarias etc.) impiden a la Administración Pública hacer un uso indiscriminado de instituciones jurídico privadas. Amén de ello, la actuación de la Administración debe regirse sobre el binomio legalidad - eficiencia. Sólo en esos términos será posible dar cumplimiento a la exigencia constitucional recogida en los Arts. 


\section{CE y 209 CN.}

- Para facilitar la tarea anterior, es decir, el discernimiento de aquellas actividades de la Administración que pueden ser ejercidas mediante instituciones iusprivatistas, la doctrina ha ido decantando algunas pautas. Entre otras, deberá hacerse uso de la "forma jurídica pública" y de las normas de derecho público toda vez que la actividad implique el ejercicio de potestades strictu sensu administrativas o de "función pública" (v.gr. ordenación, control, inspección, vigilancia, sanción etc.) o bien manifestaciones de superioridad de la Administración frente a los particulares.

- En el mismo sentido, con independencia de su prestación en régimen de concurrencia, los servicios públicos "esenciales" (incluidos los asistenciales), así definidos por el Legislador, deben ser prestados por el "sector público", sin menoscabo de las garantías del administrado. Esta afirmación parece sugerir la necesidad del uso de formas públicas y la sumisión al régimen de derecho público.

- Por el contrario, la Administración Pública está facultada para hacer uso de las formas jurídicas propias del derecho privado para gestionar las actividades de producción y puesta en el mercado de bienes y servicios. Sin embargo, con independencia de las herramientas públicas o privadas escogidas, la Administración, cuando intervenga en actividades económicas, deberá hacerlo en condiciones de igualdad y bajo el respeto de la normativa de libre competencia.

- Junto al sector de la contratación, las sociedades anónimas públicas son el ejemplo característico de institución jurídica privada utilizada por la Administración pública para eludir los controles de su propio derecho. Pese a ello, la sola remisión legal de la institución a las normas derecho privado no parece suficiente para determinar su verdadera naturaleza jurídica.

- En este sentido, hemos citado los criterios más recurridos por el legislador, la jurisprudencia y la doctrina para determinar si, no obstante su remisión formal al derecho privado, la sociedad participada por dineros públicos debe considerarse pública y regirse por normas de derecho público. Las pautas tradicionales enunciadas por las diversas legislaciones para clasificar una sociedad participada por dineros públicos como de derecho público o privado (personalidad jurídica - forma jurídica utilizada - propiedad del capital) se han visto superadas por la realidad actual. El indicador más acertado para determinar la naturaleza jurídica de las sociedades participadas por dineros públicos parece ser el denominado por la doctrina como "control público".

- En aplicación de este último criterio, aquellas sociedades participadas por dineros públicos sometidas a un régimen legal mixto o que estén en la posibilidad de ser controladas por los poderes públicos (lo que conlleva que la sociedad actué con privilegios de los que carece el sector privado) 
son de naturaleza pública. Con independencia del régimen jurídico al que esté remitida en su norma de creación o en sus estatutos, son parte de la Administración Pública y deben regirse por normas de derecho público.

- Los excesos en el ejercicio de las potestades administrativas o el uso inadecuado de los instrumentos de intervención económica deben ser enjuiciados - en el marco de sus competencias - bien ante las Cortes o Tribunales Constitucionales, bien ante la Jurisdicción Contenciosoadministrativa. Estos órganos judiciales están dotados de los poderes necesarios para determinar la instrumentalidad de los entes (creados por la Administración) cuyo ejercicio se somete a normas de derecho privado y remitir su titularidad final a la Administración Pública; asimismo resultan plenamente legitimados para enjuiciar el "núcleo público" que se encuentra en la base de toda actuación pública endosada al derecho privado.

- Todo lo anterior, podrá servir como base para el desarrollo de una necesaria reflexión alrededor de aquella tendencia reformadora que, en nombre de un mal entendido liberalismo económico, ha hecho de la "apertura del mercado" y de la "desregularización" sus manifiestos. La actual crisis económica -cuya responsabilidad debe probablemente adscribirse, entre otros factores, también a un malentendido acerca de la diferenciación entre público y privado y a una general confusión entre libre iniciativa privada y ausencia de control por parte de la Administración-, podría representar la ocasión esperada para volver a plantear con insistencia una nueva "vuelta al Derecho administrativo", en el claro entendimiento que las exigencias de eficacia y eficiencia de la Administración pública no son elementos a buscarse fuera de la cosa pública, sino que, por expreso mandato constitucional, han de predicarse de la propia Administración.

\section{REFERENCIAS}

Alonso Ureba, A.(1985). La empresa pública: aspectos jurídicos-constitucionales $y$ derecho económico, Madrid,

Alonso Ureba, A. (1986). El marco constitucional económico español y la adehesión a las Comunidades Europeas, en: Tratado de Derecho Comunitario Europeo, vol. I, Madrid,

Andrés Ibañez, P. (1997). Contra las inmunidades del poder: una lucha que debe continuar, en: Revista Española de Derecho Administrativo, Núm.93,

Ariño Ortíz, G. (1994). ¿Privatizar el Estado? un retroceso en el camino de la historia o la antítesis del Estado de Derecho, Madrid.

Boquera Oliver, J. M. (194). La sistematización del derecho administrativo desde la personalidad jurídica de la Administración del Estado, en: Administración Instrumental. Libro homenaje a Manuel Francisco Clavero Arévalo, vol. II, Madrid,

Borrajo Iniesta, I. (1993). El intento de huir del derecho administrativo, en: 
Revista Española de Derecho Administrativo, Núm.78.

Clavero Arevalo, M. Personalidad jurídica, derecho general y derecho singular en las Administraciones Autónomas, en: Documentación Administrativa.

Del Saz Cordero, S., (1993). Desarrollo y criris del derecho administrativo, su reserva constitucional, en: Nuevas perspectivas del derecho administrativo. 3 estudios, Madrid.

Del Saz Cordero, S. (1994).La huída del derecho administrativo: ultimas manifestaciones, aplausos y críticas, en: Revista de Administración Pública, Núm. 133.

Duguit, L. and Posada, A. (2006). Las transformaciones del derecho público, Pamplona,

Duque, J. (1978). Constitución económica y Derecho Mercantil en La reforma de la legislación mercantil, Madrid.

Esteban Velasco. (1982). El poder de decisión en las sociedades anónimas, Madrid.

Esteve Pardo, J. (1994). La personalidad jurídica en el derecho público y la dialectica Estado-sociedad. Prespectiva histórica, en Administración Instrumental. Libro homenaje a Manuel Francisco Clavero Arévalo, Madrid.

Fernández Rodríguez, T. R. (1994). Arbitrariedad y Discrecionalidad, Madrid,

Font Galan, J. (1979). Notas sobre el Modelo Económico de la Constitución Española, en: Revista de Derecho Mercantil Núm. 152.

García de Enterría, E. (1985). La Constitución como norma y el Tribunal Constitucional, Madrid.

García de Enterría, E. (1994).El concepto de pesonalidad jurídica en el derecho público, en: Administración Instrumental. Libro homenaje a Manuel Francisco Clavero Arévalo, vol. II, Madrid.

García de Enterría, E. and Fernández Rodríguez, T. R. (2008). Curso de Derecho Administrativo vol. I, Madrid.

García de Enterría, E. and Martínez- CARAnde. (1962).La lucha contra las inmunidades del poder en el Derecho Administrativo, Madrid.

García Echevarría, S. (1982). El orden económico en la Constitución, en: Libre empresa, Madrid.

García Ruiz, E. (2006) La nueva sociedad anónima pública, Madrid.

García Torres, J. and Jiménez- Blanco, A. (1986).Derechos fundamentales y relaciones entre particulares, Madrid.

Garrido Falla, F. (1981). Introducción general, en: El modelo económico de la Constitución Española, Madrid.

Garrido Falla, F. (1994). El concepto de servicio público en el Derecho Español, en: Revista de Administración Pública, Núm. 135. 
Girón Tena, J. (1976). Derecho de Sociedades, Madrid.

Houin, R. (1952). La gestion des entreprises publiques et les methodes du droit commercial, en: Archives de philosophie du droit.

Lafuente Benachez, M., "Las nociones de Administración Pública y personalidad jurídica", en Administración Instrumental. Libro homenaje a Manuel Francisco Clavero Arévalo, Madrid, 1994,

Laguna de Paz, J. C. (1995). La renuncia de la Administración Pública al derecho administrativo, en: Revista de Administración Pública.

Martín Navamuel, J. (1993). La gestión tributaria en el nuevo Impuesto de la Renta de Personas Físicas, en: Escritos jurídicos en memoria de Luis Mateo Rodríguez, vol. I, Santander.

Martín Retortillo, S. (1988). Derecho Administrativo Económico, Madrid.

Martín Retortillo, S. (1996). Reflexiones sobre la huida del derecho administrativo, en: Revista de Administración Pública, Núm. 140.

Menéndez Menéndez, A. (1985). Consitución, sistema económico y derecho mercantil Madrid.

Montoro Romero, C. (1986). La privatización entre la crisis del Estado de bienestar y la crisis de identidad de la empresa pública, en: Economistas, Núm.19.

Montoya Marti, E. (1996). Las empresas públicas sometidas al derecho privado, Madrid.

Morillo-Velarde Pérez, J. I. (1994). La huída del derecho administrativo, la personalidad jurídica de las Administraciones Públicas y el principio de eficacia. Reflexiones, en: Administración Instrumental. Libro Homenaje a Manuel Francisco Clavero Arévalo, vol. II, Madrid.

Morisi, M. (1980). Aspectos esenciales de la relación entre el Estado y la Economía en la Constitución de la crisis, en: La Constitución Española de 1978, Madrid.

Muñoz Machado, S. (1993). Público y privado en el mercado europeo de la TV, Madrid.

Nieto, A. (1991). La Administración sirve con objetividad a los intereses generales, en: Estudios de la Consitución Española homenaje al Prof. Eduardo García de Enterría, Madrid.

Ottaviano, V. Considerazioni sugli Enti Pubblici Strumentali, Padova, 1959,

Parada Vázquez, R. (2008). Derecho Administrativo II. Organización y empleo público, Madrid.

Parejo Alfonso, L. (1993). Ámbito de aplicación y principios generales de la Ley de Régimen Jurídico de las Administraciones públicas y Procedimiento Administrativo Común, “ en La nueva Ley de régimen jurídico de las Administraciones públicas y procedimiento administrativo común, Madrid. 
Piñar Mañas, J. L. (1994). Privatización de la empresa púlica y Derecho Comunitario", en Revista de Administración Pública, Núm. 133.

Rivero, J. (1956). Hauriou et l'avènement de la notion de service public, en: L'evolution du droit public. Etudes en l'honneur d'Archille Mestre, París.

Rivero Ortega, R. (1998). Administraciones Públicas y Derecho Privado, Madrid.

Rodríguez-Arana Muñoz, J. (1991). La privatización de la empresa pública, Madrid.

Rodríguez Curiel. (1991). El control comunitario de las ayudas públicas, en: Noticias de la Unión Europea, Núm 75.

Sala Arquer, J. (1992). Huída al derecho privado y huída del derecho, en: Revista Española de Derecho Administrativo, Núm. 75.

Salvador Armendáriz, M. (2000). Banca Pública y Mercado, Madrid.

Sánchez Morón, M. (1984). Notas sobre la función administrativa en la Consitución Española de 1978, en: La constitución española de 1978, Madrid.

Uprimny, R. and Rodríguez, C. (2005). Constitución y modelo económico en Colombia: hacia una discusión productiva entre economía y derecho", en: Debates de Coyuntura Económica, Núm. 62.

Verguez, M. (1979). El derecho mercantil ante la Constitución española, en:Lectura sobre la Constitución española, Madrid.

Villar Palasi, J. L. (1950). La actividad industrial del estado en el derecho administrativo, en Revista de Administración Pública, Núm. 3.

Vincent Chulia, F. (1993). Poderes públicos y derecho de la competencia, en: Revista General de Derecho, Núm. 583.

Zanobini, G., corso di dirito amministrativo, vol. I, Milán, 1958, 
